\title{
Effects of Simulated Acid Rain on Growth and Yield of Cassava Manihot esculenta (Crantz)
}

\author{
B. O. Odiyi ${ }^{1} \&$ J. F. Bamidele ${ }^{2}$ \\ ${ }^{1}$ Department of Biology, School of Sciences, Federal University of Technology, Akure, Ondo state, Nigeria \\ ${ }^{2}$ Department of Plant Biology and Biotechnology, University of Benin, Benin City, Nigeria \\ Correspondence: B. O. Odiyi, Department of Biology, School of Sciences, Federal University of Technology, \\ PMB 704, Akure, Ondo state, Nigeria. Tel: 234-803-563-9111. E-mail: bnyamali@yahoo.com
}

Received: June 28, 2013 Accepted: September 26, 2013 Online Published: December 15, 2013

doi:10.5539/jas.v6n1p96 URL: http://dx.doi.org/10.5539/jas.v6n1p96

\begin{abstract}
Southern Nigeria is a major cassava producing area that has been subjected to air pollution from increasing industrial activities and population explosion in the coastal towns and cities. The level of pollution is not expected to change drastically in the immediate future. Investigations were carried out to study the changes in the morphology, survival, growth and yield of TMS 96/1672 cultivar of cassava Manihot esculenta (Crantz) to simulated acid rain. The plants were exposed to simulated acid rain of $\mathrm{pH}$ 2.0, 3.0, 4.0, 5.0, 6.0 and 7.0 (control) respectively. Simulated acid rain induced morphological changes including chlorosis, early leaf senescence, necrosis, leaf abscission, leaf folding and death. Plant height, leaf area, fresh weight, dry weight, relative growth rate, chlorophyll content and the harvest index was the highest at $\mathrm{pH} 7.0$ (control) and significantly $(\mathrm{p}<0.05)$ decreased with increasing acidity. The results indicates that TMS 96/1672 cultivar of Manihot esculenta exhibited growth stimulation at low acidity of $\mathrm{pH} 2.0$ and it is likely to be retarded in future due to rapid and uncontrolled industrialization.
\end{abstract}

Keywords: lesions, photosynthetic pigment, dehydration, Manihot esculenta, root production

\section{Introduction}

Acid rain is a major polluting event harmful to terrestrial and aquatic ecosystems (Brimblecombe et al., 2007). It is the wet deposition of pollutants such as oxides of sulphur and nitrogen contained in power plant emission, factory smoke and car exhaust, react with the moisture in the atmosphere (Kita et al., 2004). In natural conditions atmospheric precipitation is slightly acidic due to the dissolution of atmospheric carbon dioxide. Rain that presents a concentration of $\mathrm{H}^{+}$ions greater than $2.5 \mu \mathrm{eq}^{-1}$ and $\mathrm{pH}$ values lower than 5.6 is considered as acid. Acid deposition may cause decline in health and growth of trees as well as other plants (Wyriwicha \& Sklodowska, 2006). Several experiments have been carried out in the field and in greenhouses to investigate the effect of acid rain in plants (Silva et al., 2005). Acid rain exposure of plants results in characteristic foliar injury symptoms, modified leaf anatomy (Stoynora \& Velikova, 2004), structural changes in the photosynthetic pigment apparatus and a decrease in the chlorophyll concentrations (Sant' Anna-Santos et al., 2006) and has reported reduction in plant growth and yield of field corn (Banwart et al., 1988), green pepper (Shripal et al., 2000) and tomato (Dursun et al., 2002).

Cassava (Manihot esculenta Crantz) belongs to the family Euphorbiaceae (Nweke et al., 2002). Since the introduction into Nigeria it has become very popular throughout the country. It is grown in $70 \%$ of the Nigerian states, available from the swamp forest area to the Guinea savannah of Nigeria. Aside being a major source of food in Nigeria, other important products produced from cassava such as starch, beer, vinegar and alcohol. The cassava cultivar TMS 96/1672 is grown in most of the Nigerian home gardens and even on large scale production. The tuber is used for human consumption in three processed forms, the toasted meal 'garri', the retted meal and the flour. 'Garri' is the most popular form of consumption in Africa. The leaves are used as a leaf vegetable. The objective of the present study was to examine the growth and productivity of cassava cultivar TMS 96/1672 under simulated acid rain. 


\section{Materials and Methods}

\subsection{Planting Procedure}

A field experiment was conducted in the school farm of the Federal University of Technology, Akure, Ondo state, Nigeria from October 2012 to March 2013. Stem cuttings of $30 \mathrm{~cm}$ long each of TMS 96/1672 cultivar of $M$. esculenta were planted horizontally with a spacing of $100 \mathrm{~cm}$ and four stem cuttings were planted on each row. Each $\mathrm{pH}$ treatment had four replicates and was arranged in a Completely Randomised Design (CRD). The plants were watered every other day and grown for a week before the application of the simulated acid rain treatment. The experimental field was hoe weeded as necessary. Simulated acid rain was sprayed to the planted cassava cultivars according to their $\mathrm{pH}$ values of 2.0, 3.0, 4.0, 5.0, 6.0 and 7.0 which was the control. The solutions were applied using a medium size pressurized sprayer on the plants. The plants grew for twenty five weeks before the experiment was terminated.

\subsection{Preparation of Simulated Acid Rain}

The acids used was an acidic mixture of concentrated sulphuric acid $\left(\mathrm{H}_{2} \mathrm{SO}_{4}\right)$ and concentrated nitric acid $\left(\mathrm{HNO}_{3}\right)$ in 2:1 ratio. The acidic solution was then calibrated using distilled water with a Deluxe $\mathrm{pH}$ meter to get the desired $\mathrm{pH}(2.0,3.0 .4 .0,5.0$ and 6.0) and cross checked with $\mathrm{pH}$ pen. The control $\mathrm{pH}(7.0)$ had distilled water.

Several parameters were used in assessing the growth and productivity of the plant. The height of shoots was measured using a tape rule in $(\mathrm{cm})$ from the soil level to the terminal bud. The measurements were taken in an interval of 2 weeks from the day the acid rain treatment commenced to the day of harvest. Leaf area was determined by the proportional method of weighing a cut-out of traced area of the leaves on graph paper with standard paper of known weight to area ratio. The fresh and dry weights were determined after twenty four weeks of treatment following the method of Hunt (1990). Relative growth rate (RGR) was calculated following the methods of Hunt (1990) and the fresh weight of the whole plant was used to determine the relative growth rate.

$$
\begin{gathered}
\mathrm{RGR}=\left(\text { loge } \mathrm{W}_{2}-\text { loge }_{1}\right) /\left(\mathrm{T}_{2}-\mathrm{T}_{1}\right) \\
\text { Where: } \mathrm{W}_{2}=\text { final weight } \\
\mathrm{W}_{1}=\text { initial weight } \\
\mathrm{T}_{2}=\text { final time } \\
\mathrm{T}_{1}=\text { initial time. }
\end{gathered}
$$

The chlorophyll content of the leaves was determined by the following method. Three grams $(3 \mathrm{~g})$ of the youngest leaves of each seedling was ground with few grains of washed sand (sand washed with concentrated $\mathrm{H}_{2} \mathrm{SO}_{4}$ and then thoroughly washed with distilled water). Chlorophyll was extracted with $20 \mathrm{ml}$ of $80 \%$ acetone and centrifuged at $2500 \mathrm{rpm}$ for 15 minutes. The clear supernatant was collected and the absorbance read at $645 \mathrm{~nm}$ and $663 \mathrm{~nm}$ on Spectronic 20 Spectrophotometer with $80 \%$ acetone as reference blank.

The harvest index was determined by the method of Ekanayake (1994).

\subsection{Statistical Analysis}

$$
\text { Harvest Index }(\mathrm{HI})=\frac{\text { Tuber dry weight }}{\text { Total plant dry weight }}
$$

Data obtained were subjected to analysis using the Statistical Package for Social Sciences, Version 15.0 (SPSS, 2003). Treatment means were separated using the Duncan's Multiple Range Test (Zar, 1984).

\section{Results}

Morphological changes were observed in TMS 96/1672 cultivar of throughout the period of the experiment. Table 1 shows the effects of simulated acid rain on the morphology of TMS 96/1672 at 24 weeks after simulated acid rain treatment. Leaves turned brownish, withered with $70 \%$ leaf abscission. The dropping and eventual collapse of leaves stretched over a period of 16-20 weeks. At $4.0 \mathrm{pH}$ treatment, leaf abscission started with the leaves at the base of the shoot droppings with long petiole. Leaves were chlorotic and necrotic. 
Table 1. Morphological changes observed in TMS 96/1672 cultivar of Manihot esculenta polluted with simulated acid rain 24 weeks after treatment

\begin{tabular}{|c|c|}
\hline $\mathrm{pH}$ Treatments & Observed effects \\
\hline 7.0 (Control) & Luxuriant growth \\
\hline 6.0 & Good growth. Leaves had small brownish dots on its surface. \\
\hline 5.0 & $\begin{array}{l}\text { Production of new leaves on the stem and at the leaf apex. Growth was retarded. There was } \\
100 \% \text { survival. Older leaves showed signs of curling and chlorosis. Had increased brownish } \\
\text { spots on the leaf surface. }\end{array}$ \\
\hline 4.0 & $\begin{array}{l}\text { The leaves were curled and chlorotic. Plant growth was stunted. Leaves were showing signs } \\
\text { of burnt surfaces from the tip. Had } 70 \% \text { leaf abscission. There was } 100 \% \text { survival. }\end{array}$ \\
\hline 3.0 & $\begin{array}{l}\text { Plants had stunted growth. The new leaves became folded, chlorotic followed by necrosis and } \\
\text { eventually some of the plants died. } 50 \% \text { survival. } 70 \% \text { leaf abscission. }\end{array}$ \\
\hline 2.0 & $\begin{array}{l}\text { Had stunted growth. } 40 \% \text { survival. All the surfaces of the leaves were necrotic and curled. } \\
\qquad \text { Had } 60 \% \text { leaf abscission from the base of the shoot. }\end{array}$ \\
\hline
\end{tabular}

Table 2. Effect of simulated acid rain (SAR) on the plant height $(\mathrm{cm})$, leaf area $(\mathrm{cm})$, fresh weight $(\mathrm{g})$, dry weight (g) of TMS 96/1672 cultivar of Manihot esculenta, 24 weeks after treatment

\begin{tabular}{ccccc}
\hline $\mathrm{pH}$ of SAR & Plant height $(\mathrm{cm})$ & Leaf area $(\mathrm{cm})$ & Fresh weight $(\mathrm{g})$ & Dry weight $(\mathrm{g})$ \\
\hline $7.0($ Control $)$ & $162.20 \pm 4.26 \mathrm{a}$ & $320.40 \pm 4.10 \mathrm{a}$ & $900.21 \pm 0.18 \mathrm{a}$ & $432.40 \pm 0.21 \mathrm{a}$ \\
\hline 6.0 & $84.62 \pm 4.12 \mathrm{~b}$ & $278.48 \pm 3.21 \mathrm{~b}$ & $720.40 \pm 0.12 \mathrm{~b}$ & $386.16 \pm 0.18 \mathrm{~b}$ \\
5.0 & $80.10 \pm 3.24 \mathrm{~b}$ & $254.36 \pm 3.10 \mathrm{~b}$ & $500.23 \pm 0.10 \mathrm{c}$ & $316.27 \pm 0.15 \mathrm{~b}$ \\
4.0 & $71.89 \pm 3.12 \mathrm{~b}$ & $230.24 \pm 2.12 \mathrm{~b}$ & $364.16 \pm 0.08 \mathrm{~d}$ & $248.54 \pm 0.11 \mathrm{c}$ \\
3.0 & $42.13 \pm 2.30 \mathrm{c}$ & $170.16 \pm 2.07 \mathrm{c}$ & $282.10 \pm 0.07 \mathrm{e}$ & $164.18 \pm 0.08 \mathrm{~d}$ \\
2.0 & $34.81 \pm 2.14 \mathrm{~d}$ & $142.18 \pm 1.52 \mathrm{c}$ & $124.28 \pm 0.03 \mathrm{f}$ & $90.40 \pm 0.03 \mathrm{e}$ \\
\hline
\end{tabular}

Each value is a mean of \pm standard error of three replicates. Means within the same column followed by the same letter are not significantly different at $(\mathrm{P}>0.05)$ from each other using New Duncan Multiple Range Test.

The results on the plant height, leaf area, fresh and dry weights are presented in Table 2 . There was a significant decrease in acidity concentrations of the parameters. The plant had the highest plant height, leaf area, fresh weight and dry weight significantly higher $(\mathrm{p}<0.05)$ at the control $(\mathrm{pH} 7.0)$ compared to the other acidity treatments.

Table 3. Effect of simulated acid rain (SAR) on the relative growth rate $\left(\mathrm{gg}^{-1} \mathrm{~d}^{-1}\right)$, chlorophyll content (mg/g) and harvest index of TMS 96/1672 cultivar of Manihot esculenta, 24 weeks after treatment

\begin{tabular}{cccc}
\hline $\mathrm{pH}$ of SAR & Relative growth rate & Chlorophyll content & Harvest index \\
\hline 7.0 (Control) & $2.8 \pm 0.26 \mathrm{a}$ & $2.7 \pm 0.20 \mathrm{a}$ & 0.5 \\
\hline 6.0 & $2.5 \pm 0.21 \mathrm{a}$ & $2.0 \pm 0.18 \mathrm{a}$ & 0.4 \\
5.0 & $1.8 \pm 0.20 \mathrm{~b}$ & $1.4 \pm 0.14 \mathrm{~b}$ & 0.3 \\
4.0 & $1.5 \pm 0.18 \mathrm{~b}$ & $1.2 \pm 0.10 \mathrm{~b}$ & 0.2 \\
3.0 & $1.0 \pm 0.14 \mathrm{~b}$ & $0.7 \pm 0.07 \mathrm{c}$ & 0.1 \\
2.0 & $0.6 \pm 0.06 \mathrm{c}$ & $0.3 \pm 0.03 \mathrm{c}$ & 0.1 \\
\hline
\end{tabular}

The effect of simulated acid rain on the relative growth rate (RGR), the chlorophyll content and the harvest index is presented in Table 3. The cultivar had the relative growth rate, the chlorophyll content and the harvest index significantly higher $(\mathrm{p}<0.05)$ at $\mathrm{pH} 7.0$ compared to the other acidity treatments. There was a significant reduction in the relative growth rate, the chlorophyll content and the harvest index with decreasing $\mathrm{pH}$ level. 


\section{Discussion}

Simulated acid rain treatment deposited on leaves affect mainly the epidermal cells causing erosion of the cuticle and altering the leaf permeability (Evans, 1984). Symptoms of plants polluted with simulated acid rain include chlorosis, necrosis, stunted growth, lesion, suppression of leaf production, leaf curling, withering of leaves, leaf abscission and even death of plants. Silva et al. (2006) found that plants exposed to low pH rain (pH 3.0) are generally retarded with leaf chlorosis, necrotic spot coupled with dehydration of the plants. Simulated acid rain exposure caused chlorosis, necrotic lesions and leaf tip injuries at different $\mathrm{pH}$ levels (Table 1). Necrosis progressed from nodal region to the adjacent inter-nodal region leading to large scale leaf abscission. Marked chlorotic and marginal necrotic symptoms were observed at $\mathrm{pH} 4.0$ and 5.0. However, this was less pronounced in comparison to $\mathrm{pH} 3.0$ and pH 2.0. Similar symptoms were also observed by Huany et al. (2005) on wheat at pH 4.3 and 2.3.

TMS 96/1672 cultivar of Manihot esculenta showed marked decrease in growth parameters compared to the control. Simulated acid rain at pH 2.0 caused characteristic burned irregular lesions on the plant leaves. It is well reported by many workers that plants sensitive to acid rain can present changes in their morphology, anatomy, physiology and biochemistry (Neufeld et al., 1985). All the plant growth parameters studied the plant height, leaf area, fresh weight and dry weight were decreased significantly at all acidity levels with respect to the control set and highest reduction were observed at $\mathrm{pH} 2.0$ level (Table 2). The adverse effects of simulated acid rain on plant growth parameters on several crops were observed by (Halman et al., 2008; Evans et al., 1997; Banwart et al., 1990).

Photosynthetic pigments were also inhibited with respect to acidity levels. Chlorophyll content was significantly reduced by simulated acid rain treatment relative to the control at $\mathrm{pH} 2.0$ and $\mathrm{pH} 3.0$ (Table 3). The greater foliar injury noticed in plants exposed to $\mathrm{pH} 2.0$ is associated with the decreased chlorophyll content and the damage to the photosynthetic apparatus. This is similar to the earlier results of Liu et al. (2010) and Evans (1984). Reduction was due to the removal of $\mathrm{Mg}^{+}$from the tetrapyrol ring of the chlorophyll molecules by $\mathrm{H}^{+}$(Foster, 1990) or due to increase of transpiration by acid rain (Evans et al., 1997). Recently similar results were also observed on many crops like mustard, radish, potato, bean plant Chehregani (2007); Agrawal et al. (2005); Kausar et al. (2005); Khan and Devpura (2005); Varshney et al. (2005).

Relative growth rate and harvest index was highest at $\mathrm{pH} 2.0$ and $\mathrm{pH} 3.0$ compared to the control plants (Table 3) and this have been reported by a number of authors (Steinfeld et al., 1998; Ekanayake, 1994; Cock et al., 1977). According to Iglesias et al. (1994), harvest index of 0.5-0.6 is the optimum level because at higher values of harvest index, root production decreases due to reduced leaf area, light interception and photosynthesis.

\section{Conclusion}

It is evident from this study that simulated acid rain treatment at $\mathrm{pH} 2.0$ and 3.0 markedly suppressed growth and yield of TMS 96/ 1672 cultivar of Manihot esculenta due to reduction of photosynthesis as a result of chlorosis, necrosis and leaf abscission. This result shows that TMS 96/1672 cultivar is likely to be retarded in future in view of rapid and uncontrolled industrialization as well as global warming. More varieties of cassava should be tested for their tolerance/ sensitivities to acidic precipitation.

\section{References}

Agrawal, S., Raghav, D., \& Khan, A. A. (2005). An evaluation of the impact of simulated acid rain on the growth of mustard in pots. Test of Agrochemicals and Cultivars, (Supplement), 21, 25-26.

Banwart, W. L., Finke, R. L., Porter, P. M., \& Hassett, J. J. (1990). Sensitivity of twenty soybean cultivars to $\begin{array}{lll}\text { simulated acid rain. Journal of Environmental Quality, 19, 339-346. } & \text {. }\end{array}$ http://dx.doi.org/10.2134/jeq1990.00472425001900020023x

Banwart, W. L., Porter, P. M., Ziegler, E. L., \& Hassett, J. J. (1988). Growth parameters and yield component response of field corn to simulated acid rain. Environ. Expt. Bot., 28, 43-51. http://dx.doi.org/10.1016/0098-8472(88)90045-7

Brimblecombe, P., Hara, H., Houle, D., \& Novak, M. (2007). Acid rain: Deposition to recovery. Lavoisier Publ., Paris. France. http://dx.doi.org/10.1007/978-1-4020-5885-1

Chehregani, A. (2007). Effects of acid train on the developmental stages of ovules and seed proteins in bean plants (Phaseolus vulgaris L). American Journal of Plant Physiology, 2, 367-372. http://dx.doi.org/10.3923/ajpp.2007.367.372 
Dursun, A., Kumlay, A. M., Yilderin, E., \& Guvenc, I. (2002). Effects of simulated acid rain on plant growth and yield of tomato. Acta Hort., 579, 245-248.

Ekanayake, I. J. (1994). Terminology for growth analysis of cassava. Tropical Root and Tuber Crops Bulletin, 8(1), 2.

Evans, L. S. (1984). Botanical aspects of acidic precipitation. Botanical Review, 50, 449-490. http://dx.doi.org/10.1007/BF02862631

Evans, L. S., Gmor, N. F., \& Dacosta, F. (1997). Leaf surface and histological perturbations of leaves of Phaseolus vulgaris and Helianthus annuи after exposure to simulated acid rain. American Journal of Bot., 4, 304-313.

Foster, J. R. (1990). Influence of $\mathrm{pH}$ and plant nutrients status onion fluxes between tomato plants and simulated acid mists. New Phytologist, 116, 475-485. http://dx.doi.org/10.1111/j.1469-8137.1990.tb00533.x

Halman, J. M., Schaberg, P. G., Hawley, G. J., \& Eagar, C. (2008). Calcium addition at the Hubbard Brook Experimental Forest increases sugar storage, antioxidant activity and cold tolerance in native red spruce (Picea rubens). Tree Physiology, 28(6), 855-862. http://dx.doi.org/10.1093/treephys/28.6.855

Huang, X. H., Zeng, O. L., \& Zhon, Q. (2005). Effect of acid rain on seed germination of rice, wheat and Grape Huan Jing Kexne, 26(1), 181-184.

Hunt, R. (1990). Basic Growth Analysis: Plant Growth Analysis for Beginners. London, UK: Academic Press. http://dx.doi.org/10.1007/978-94-010-9117-6

Iglesias, C. A., Calle, F., Hershey, C., Jaramillo, G., \& Mesa, E. (1994). Sensitivity of cassava (Manihot esculetna Crantz) clones to environmental changes. Field Crops Research, 36, 213-220. http://dx.doi.org/10.1016/0378-4290(94)90113-9

Kausar, S., Khan, A. A., \& Rahman, F. (2005). Impact of simulated acid rain on potato. In Herbal Drug and Environmental Pollution. A satellite Session of Third International Conference on Plants and Environmental Pollution, Jamia Hamdard, New Delhi.

Kawano, K. (1978). Genetic improvement of cassava (Manihot esculenta Crantz) for productivity, Trop. Agric. Res. Ser., 11, 9-21.

Khan, T. I., \& Deopura, S. (2005). Physiological and biochemical effects of simulated acid rain on Phaseolus vulgaris Var HUR 15. The Environmentalist, 24, 224-226.

Kita, I., Sato T., Kase, Y., \& Mitropoulos, P. (2004). Neutral rains at Athens, Greece: a natural safeguard against acidification of rains. Science Total Environment, 327, 285-294. http://dx.doi.org/10.1016/j.scitotenv.2004.01.012

Liu, K. H., Mansell, R. S., \& Rhue, R. D. (2010). Cation removal during application of acid solution into air dry soil columns. Soil Science Society Journal, 4, 1747-1753.

Neufeld, H. S., Jernstedt J. A., \& Haines, B. L. (1985). Direct foliar effect of simulated acid rain. I. Damage, $\begin{array}{lllll}\text { growth and gas } & \text { exchange. New Phytologist, }\end{array}$ http://dx.doi.org/10.1111/j.1469-8137.1985.tb03667.x

Nweke, F. I., Spencer, S. C., \& Lyman, J. K. (2002). The cassava transformation. African best kept secret, Michigan state University press, East Lansing, Michigan, USA.

Sant' Anna-Santos, B. F., Silva, L. C., Azevedo, A., \& Deque-Brasil, R. (2006). Effects of simulated acid rain on photosynthesis, Chlorophyll fluorescence and antioxidative enzymes in Cucumis sativus L. Photosynthetica, 40,331-335.

Seinfield, J. H., Pandis, S. N., \& Spyries, N. (1998). Atmospheric chemistry and physics from air pollution to climate damage. AVI publishing Co, West Print Connecticut.

Shripal, N., Pal, K. S., \& Kumar, N. (2000). Effects of simulated acid rain on yield and carbohydrate contents of green pepper. Advan. Plant Sci., 13, 85-88.

Silva, L. C., Azevedo, A. A., Silva, E. A., \& M., Oliva, M. A. (2005). Effects of simulated acid rain on the growth and anatomy of five Brazilian tree species. Australian Journal of Botany, 53, 789-796. http://dx.doi.org/10.1071/BT04096

Silva, L. C., Oliva, M. A., Azevedo, A. A., \& Araujo, J. M. (2006). Responses of resting plant species to pollution from an iron pelletization factory. Water Air and Soil Pollution, 175(1-4), 241-256. http://dx.doi.org/10.1007/s11270-006-9135-9 
SPSS. (2003). Statistical package for social sciences (SPSS 15.0 Inc., Chicago, U.S.A).

Stoynora, D., \& Velilova, V. (1998). Effects of simulated acid rain on chloroplast ultrastructure of primary levels of Phaseolus vulgaris. Biological plant, 40, 589-598.

Varshney, P., Kausar, S., \& Khan, A. A. (2005). An evaluation of the susceptibility of radish in pots to simulated acid rain. Test of Agrochemical Cultivar, 27, 29-30.

Wyrwicha, A., \& Sklodowska, M. (2006). Influence of repeated acid rain treatment on antiocidative enzyme activities and on lipid peroxidation in cucumber leaves. Environmental and Experimental Botany, 56, 198-204. http://dx.doi.org/10.1016/j.envexpbot.2005.02.003

Zar, J. H. (1984). Biostatatical Analysis (2nd ed.). Englewood Cliffs, N.J.: Prentice- Hall International.

\section{Copyrights}

Copyright for this article is retained by the author(s), with first publication rights granted to the journal.

This is an open-access article distributed under the terms and conditions of the Creative Commons Attribution license (http://creativecommons.org/licenses/by/3.0/). 